\title{
Article \\ The Effect of Red Mud Content on the Compressive Strength of Geopolymers under Different Curing Systems
}

\author{
Tao Ai *, Danni Zhong, Yao Zhang, Jingshan Zong, Xin Yan and Yanhui Niu * \\ The School of Materials Science and Engineering, Chang'an University, Xi'an 710064, China; \\ 2019131007@chd.edu.cn (D.Z.); 2019131031@chd.edu.cn (Y.Z.); z15087752959@163.com (J.Z.); \\ Xinyan@chd.edu.cn (X.Y.) \\ * Correspondence: aitao@chd.edu.cn (T.A.); niuyh@chd.edu.cn (Y.N.)
}

check for updates

Citation: Ai, T.; Zhong, D.; Zhang, Y.; Zong, J.; Yan, X.; Niu, Y. The Effect of Red Mud Content on the

Compressive Strength of Geopolymers under Different Curing Systems. Buildings 2021, 11, 298. https://doi.org/10.3390/ buildings 11070298

Academic Editors: Xi Jiang,

Pawel Polaczyk, Rui Xiao and Wei Hu

Received: 3 June 2021

Accepted: 5 July 2021

Published: 7 July 2021

Publisher's Note: MDPI stays neutral with regard to jurisdictional claims in published maps and institutional affiliations.

Copyright: (C) 2021 by the authors Licensee MDPI, Basel, Switzerland. This article is an open access article distributed under the terms and conditions of the Creative Commons Attribution (CC BY) license (https:// creativecommons.org/licenses/by/ $4.0 /)$

\begin{abstract}
To maximize the utilization of red mud in geopolymers, a red mud-metakaolin (RM-MK) geopolymer and red mud-fly ash (RM-FA) geopolymer were prepared, respectively. The effects of red mud content on the compressive strength and microstructure of the geopolymers were investigated under three different curing conditions. The results showed that the strength of the geopolymer decreased linearly with an increase in the red mud content, whether curing at room temperature or $80^{\circ} \mathrm{C}$. Surprisingly, curing in an autoclave, the appropriate amount of red mud had a favorable impact on the mechanical properties of the geopolymers. When the amount of red mud was 50\%, the strength of the RM-MK geopolymer reached its highest compressive strength, $36.3 \mathrm{MPa}$, and the strength of the RM-FA geopolymer reached its highest at $31.7 \mathrm{MPa}$. Compared with curing at low temperature, curing the red mud-based geopolymers under a higher temperature and higher pressure can maximize the use of red mud. XRD analysis indicated that zeolite minerals formed. The SEM results showed that the geopolymers cured in an autoclave had a dense structure.
\end{abstract}

Keywords: red mud; metakaolin; fly ash; geopolymer; curing system; compressive strength

\section{Introduction}

Red mud is an alkaline solid waste residue generated from the alumina-refining process of bauxite. On average, about 1 to 1.5 tons of red mud are generated from 1 ton of alumina production [1], while its utilization is extremely low [2]. Due to its high content of alkalinity and heavy metals [3], the accumulation of large areas of red mud not only occupies an enormous land area but also poses a serious threat to the surrounding soil, air, water, and human health [4]. Therefore, it urgently necessary to properly treat red mud and realize the utilization of this resource. The currently reported methods for treating red mud include [4-8] (1) recovery of valuable elements in red mud, such as $\mathrm{Fe}, \mathrm{Al}, \mathrm{Ca}$, Ti, etc.; (2) modified red mud is used as an adsorbent to absorb pollutants in air and water and improve the soil; and (3) red mud is rich in silicate components, such as $\mathrm{Si}, \mathrm{Al}, \mathrm{Fe}$, and $\mathrm{Ca}$, which can be used to prepare building materials, including cement, glass-ceramics, concrete, and brick. Typically, application in building materials can increase red mud use to the greatest extent. Much research on the application of red mud in building materials have been conducted at home and abroad. Red mud contains a large amount of iron, which has the potential to prepare high-iron aluminum cement. Zhao et al. [9] prepared sulfur aluminate cement with Bayer red mud and fly ash. The use of red mud can reduce the firing temperature of the clinker. In addition, a proper amount of red mud was beneficial to the formation of $\mathrm{C}_{4} \mathrm{~A}_{3} \mathrm{~S}$ and the improvement of compressive strength. Qi et al. [10] successfully prepared a new red mud road base material with excellent performance. Compared with traditional semi-rigid base materials, the red mud base material had a higher strength and resilience modulus, which was suitable for the construction of asphalt pavement bases for highways and expressways. Yang et al. [11] successfully developed a glass-ceramic $\mathrm{CaO}-\mathrm{SiO}_{2}-\mathrm{Al}_{2} \mathrm{O}_{3}$ system mostly with red mud 
and fly ash. The proportion of the two industrial wastes, red mud and fly ash, was up to $85 \mathrm{wt} \%$, which has significant economic and environmental benefits. Furthermore, some researchers have used red mud and solid wastes to prepare non-fired bricks and sintered bricks that met the standards [12-14]. Although the above research has good application prospects, the existence of alkaline substances and heavy metal elements in red mud limit the large-scale utilization of red mud in traditional buildings, compared to cement $[7,15]$. Moreover, the current dealkalization technology is not mature and the economic cost is too high [16].

A geopolymer is a new type of green gelling material formed by the reaction of high-silica-alumina natural minerals or solid wastes with alkaline activators. At room temperature or low temperature, the $\mathrm{Si}-\mathrm{O}$ bond and $\mathrm{Al}-\mathrm{O}$ bond in the raw material are broken under the action of the alkaline catalysts and then reorganized [17-19]. The reaction mechanism of the geopolymer is extremely complicated, and the reaction process can be summarized as three processes: dissolution-recombination-solidification. The specific reaction steps are $[20-22](1)\left[\mathrm{SiO}_{4}\right]$ and $\left[\mathrm{AlO}_{4}\right]$ from the aluminosilicate raw material are dissolved in alkaline solutions; (2) under the action of an alkali activator, the monomers are dehydrated and condensed into aluminosilicate oligomers, and the gel is formed; and (3) excess water in the gel phase is drained and an aluminosilicate polymer gel is formed. With the advantages of abundant raw materials, a simple preparation process, energy-saving, environmental protection, excellent mechanical properties, and durability [23,24], geopolymers are expected to become green cementitious material to replace Portland cement.

Red mud contains a great deal of silicon and aluminum compounds, which can be used as raw materials for geopolymers [25]; in addition, the alkalinity in red mud can be used effectively to reduce the cost. Moreover, the toxic metals in the red mud are sealed because of the special three-dimensional network structure of the geopolymer [26]. Therefore, the preparation of a geopolymer from industrial waste red mud not only follows the concept of environmental protection but also has certain application value, which is a highly effective way to realize its resource utilization.

The polymerization reaction of a geopolymer is a complicated process that is affected by many factors, such as the performance of the raw materials (e.g., reactivity, Si/Al ratio, and the quantity and characteristics of the unreacted phases), the concentration of alkaline solutions, and the curing conditions (e.g., temperature, humidity, and pressure) [27-31]. All of the factors ultimately determine the microstructure and mechanical properties of the geopolymer. To improve the activation reaction rate and increase the strength of the geopolymer, red mud is often combined with fly ash, metakaolin, ground blast furnace slag, rice husk ash, and other highly active materials. Kumar et al. [32] investigated the effect of $0-40 \%$ red mud addition on the properties of fly ash geopolymers. The results showed that the strength of the geopolymers improved with the addition of red mud but the improvement in strength was only for $5-20 \%$ of the red mud content. When the red mud content was $10 \%$, the more intense reaction, structural rearrangement, and better mechanical properties of the geopolymers were mainly attributed to the dense structure caused by the optimal sodium hydroxide concentration and available silicon and aluminum. He et al. [17] prepared a red mud-rice husk ash geopolymer with a compressive strength of $20.5 \mathrm{MPa}$ from two industrial wastes, red mud and rice husk ash, which was comparable to most Portland cement.

The curing system plays an important role in the synthesis and strength development of a geopolymer. Kani et al. [33] studied the effect of curing time and temperature on the strength development of a natural pozzolan-based geopolymer. They concluded that the increase in curing temperature and time had a positive effect on the strength of the geopolymer. Before heating, a long pre-curing time in a humid environment was beneficial to the strength development of the natural pozzolan-based geopolymer. Zhang et al. [34] investigated the reaction kinetics of red mud-fly ash-based geopolymers, and mainly analyzed the effects of curing temperature on the formation of geopolymer gels, porosity, 
and mechanical properties. He pointed out that mechanical strength is largely affected by the development of geopolymer gels and porosity, both of which were affected by the curing temperature. Studies indicated that the $\mathrm{SiO}_{2}$ in red mud was insoluble in alkaline solutions and did not participate in geological polymerization at atmospheric pressure. Therefore, the higher the red mud content was, the lower the geopolymer strength was [35]. It was found that the $\mathrm{SiO}_{2}$ in red mud can be effectively utilized to participate in the reaction by solidifying the red mud-based polymer under high temperature and high pressure in an autoclave. Hoang et al. [36] investigated the effect of the curing regime on the synthesis and properties of alkali-activated red mud materials. The $\mathrm{SiO}_{2}$ in the red mud began to dissolve. Additionally, the dissolution rate of the silica in the red mud and the mechanical properties of the materials were improved by increasing the pressure, time, and alkali liquor concentration in the autoclave. It was predicted that red mud after autoclave curing can participate in the synthesis reaction similar to fly ash under high-temperature curing, which was derived from the result that in the same concentration sodium hydroxide solution, the dissolution rate of silicon dioxide in red mud after high-temperature curing reached and exceeded that of silicon dioxide in fly ash. The solubility of $\mathrm{Al}_{2} \mathrm{O}_{3}$ both in red mud and fly ash improved with the increase of pressure, temperature, and alkali liquor concentration.

The abovementioned research studies provide a theoretical basis for the polymerization process and strength development of the red mud-based polymer. However, previous research focused on how to improve the strength of the red mud-based polymer, and there are very few studies on improving the utilization rate of red mud while increasing its strength. This article aims to increase the amount of red mud as much as possible in the process of preparing high-performance red mud-based polymers. Different proportions of a red mud-metakaolin geopolymer and red mud-fly ash geopolymer were prepared. The influence of the red mud content on the strength of the geopolymers under different curing systems was explored. To further clarify the relationship between the geopolymer synthesis conditions and mechanical properties, the phase composition and microstructure of the geopolymers under different curing systems were characterized by XRD and SEM.

\section{Materiaals and Methods}

\subsection{Materials}

Red mud (RM), metakaolin (MK), and fly ash (FA) were used as raw materials to provide aluminosilicate. The red mud used in the experiment was obtained by the Bayer process. The metakaolin was prepared by calcining kaolin at $750{ }^{\circ} \mathrm{C}$ for $4 \mathrm{~h}$. Class F fly ash was used in this experiment. The main chemical composition of each raw material in Table 1 is obtained by XRF test. It is seen from Table 1 that the content of $\mathrm{Al}_{2} \mathrm{O}_{3}$ in the red mud is higher than that of $\mathrm{SiO}_{2}$. The content of $\mathrm{Fe}_{2} \mathrm{O}_{3}$ is $34.5 \%$, which determines that the red mud appears red in appearance. The high sodium hydroxide content is the reason for the high alkalinity of red mud. Metakaolin contains a great number of aluminates, with $\mathrm{SiO}_{2}$ and $\mathrm{Al}_{2} \mathrm{O}_{3}$ accounting for more than $95 \%$. The essential components of fly ash are $\mathrm{SiO}_{2}, \mathrm{Al}_{2} \mathrm{O}_{3}, \mathrm{CaO}$, and $\mathrm{Fe}_{2} \mathrm{O}_{3}$. Figure 1 shows the XRD pattern of red mud. The main mineral composition of red mud is hematite $\left(\mathrm{Fe}_{2} \mathrm{O}_{3}\right)$, sodalite $\left(\mathrm{Na}_{8}\left(\mathrm{Al}_{6} \mathrm{Si}_{6} \mathrm{O}_{24}\right) \mathrm{Cl}_{2}\right)$, calcite $\left(\mathrm{CaCO}_{3}\right)$, anatase $\left(\mathrm{TiO}_{2}\right)$, and cancrinite $\left(\mathrm{Na}_{8}\left(\mathrm{Al}_{6} \mathrm{Si}_{6} \mathrm{O}_{24}\right)\left(\left(\mathrm{CaCO}_{3}\right)_{2}\right)\right)$. An alkaline activator was made up of sodium silicate, $95 \%$ pure sodium hydroxide, and deionized water in a certain proportion.

Table 1. The main chemical composition of the raw materials (\%).

\begin{tabular}{ccccccccc}
\hline $\begin{array}{c}\text { Chemical } \\
\text { Constituent }\end{array}$ & $\mathrm{SiO}_{2}$ & $\mathrm{Al}_{2} \mathbf{O}_{3}$ & $\mathrm{CaO}$ & $\mathrm{Fe}_{2} \mathrm{O}_{3}$ & $\mathbf{N a}_{2} \mathbf{O}$ & $\mathbf{K}_{2} \mathbf{O}$ & $\mathrm{TiO}_{2}$ & $\mathbf{S O}_{3}$ \\
\hline $\mathrm{RM}$ & 16.2 & 22.9 & 1.8 & 34.5 & 8.7 & - & 8.4 & - \\
$\mathrm{MK}$ & 51.9 & 45.45 & 0.142 & 0.93 & 0.05 & 0.445 & - & - \\
$\mathrm{FA}$ & 43 & 30.8 & 3.05 & 2.23 & 0.08 & 0.7 & - & 0.98 \\
\hline
\end{tabular}




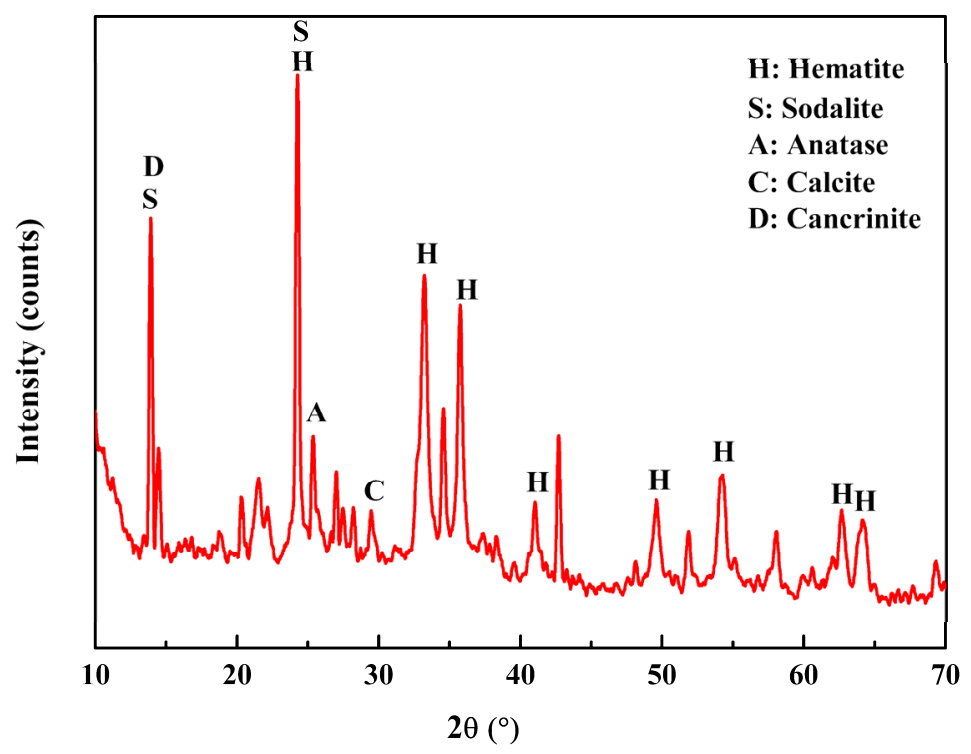

Figure 1. XRD pattern of the Bayer red mud.

\subsection{Geopolymer Synthesis}

According to the optimal value of the ratio of a high-strength geopolymer reported previously [19,37], in this study, the $\mathrm{Si} / \mathrm{Al}$ molar ratio and $\mathrm{Na} / \mathrm{Al}$ ratio of the geopolymers prepared were designed as 2 and 1, respectively. According to a water-solid ratio of 0.5 , the alkaline activator was made by mixing $8 \mathrm{~mol} / \mathrm{L}$ sodium hydroxide, sodium silicate, and deionized water in a certain ratio. Red mud and metakaolin (fly ash) were mixed with an alkaline activator to prepare the geopolymer precursor in a slurry state. A total of $5 \sim 6 \%$ distilled water was added as a regulator to ensure that the silicoaluminate raw material was fully dissolved in the alkaline solution. The mixed geopolymer slurry was poured into a plastic mold with an inner diameter of $3.6 \mathrm{~cm}$. The height of the geopolymer sample was $3.6 \mathrm{~cm}$. Subsequently, the samples were cured and molded after vibration exhaust. Compressive strength was examined by a universal testing machine. The specific experimental process is recorded in Figure 2.

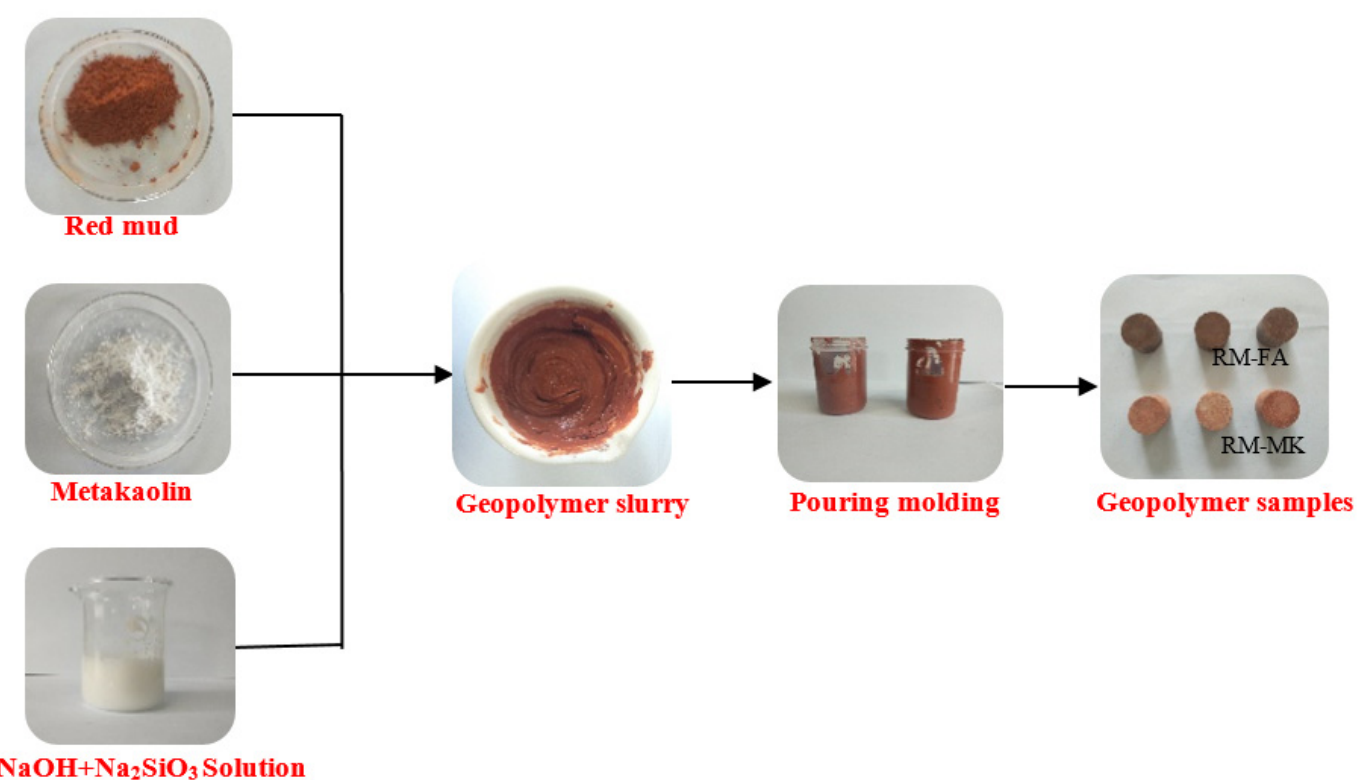

Figure 2. The preparation process of the geopolymer. 
To study the effect of curing conditions on the development of the mechanical properties of the geopolymer, three different curing methods were employed, including curing at room temperature for $7 \mathrm{~d}$, curing at $80^{\circ} \mathrm{C}$ for $24 \mathrm{~h}$, and curing at $220^{\circ} \mathrm{C}$ in the autoclave for $8 \mathrm{~h}$. One should seal the sample at $80^{\circ} \mathrm{C}$ and in the autoclave to prevent the moisture from evaporating too fast. To study the influence of red mud content on the mechanical properties of the geopolymers under different curing systems, the mass ratios of the red mud and metakaolin were set as 1:2,1:1, 2:1, and 3:1, respectively, with other factors unchanged. To ensure reproducibility, three duplicate samples were prepared for each proportion to obtain an average value.

\subsection{Characterization Methods}

\subsubsection{Compressive Strength Test}

The mechanical properties of the geopolymer were performed by an unconfined compression test. The diameter of the bottom surface of the cylinder sample was $3.6 \mathrm{~cm}$, measured by a vernier caliper, and the compression area $(S)$ was $10.2 \mathrm{~cm}^{2}$. Before the test, both ends of each sample were polished with sandpaper to ensure that the surface of both ends of the samples was smooth, to prevent the experiment error caused by uneven force. The sample was placed horizontally on the compressive strength testing machine for the test of compressive strength. The loading speed was $1 \mathrm{kN} / \mathrm{s}$. The maximum load $F(\mathrm{kN})$ when the specimen was damaged was recorded.

The calculation formula of compressive strength $F_{c u}(\mathrm{MPa})$ is as follows:

$$
F_{c u}=F / S
$$

where $F$ is the maximum load when the sample was damaged, $\mathrm{kN}$; and $S$ is the compression area of the sample, $\mathrm{m}^{2}$.

\subsubsection{Structural Characterization of the Geopolymers}

X-ray Diffraction (XRD) was used to analyze the phase composition of the geopolymers quantitatively and qualitatively. The sample was dried in a vacuum drying oven at $60{ }^{\circ} \mathrm{C}$ for $2 \mathrm{~h}$ and then ground into a powder. The mineral composition of the geopolymer powder was characterized by X-ray powder diffraction (XRD) (Brooke AXS D8 ADVANCE, Germany). XRD scans used $\mathrm{Cu} \mathrm{K} \alpha$ radiation, a scanning speed of $10^{\circ} / \mathrm{min}$, and a scan range of $10-80^{\circ} 2 \theta$ (diffraction angle). Scanning electron microscopy (SEM) was used to observe the microstructure of the reaction products. Flat and representative cross-sections were elected and sprayed with gold. A Hitachi S4800 scanning electron microscope (Hitachi, Japan) was used to observe the surface morphology and structural changes of the geopolymers at a $10 \mathrm{kV}$ scanning voltage.

\section{Results and Discussion}

\subsection{Compressive Strength}

The relationship between the content of the red mud and the compressive strength of the geopolymers under different curing systems is shown in Figure 3. It can be found that the changing trend in compressive strength of the red mud-metakaolin geopolymer and red mud-fly ash geopolymer with the content of red mud is similar. Apparently, the strength of the RM-MK geopolymer is higher than that of the RM-FA geopolymer. This result is due to the large amount of soluble aluminosilicate in metakaolin. As is shown in Figure 3a,b, curing at room temperature and $80^{\circ} \mathrm{C}$ under atmospheric pressure, the improvement in the proportion of red mud is not conducive to the development of geopolymer strength. The strength of the geopolymer decreases as the proportion of red mud increases. On the one hand, at atmospheric pressure, the insoluble silicon and low solubility aluminum in red mud cannot be used as the major source of aluminosilicate during the polymerization process, but only as inactive fillers [38]. On the other hand, the high aluminum content in red mud is another reason for the strength reduction. The Al-O bond breaks faster than the $\mathrm{Si}-\mathrm{O}$ bond [39]. The $\mathrm{Al}-\mathrm{O}$ bond is rapidly dissolved in the alkali solution and the raw 
material particles are wrapped by the generated aluminum-rich gel phase, which prevents the further dissolution process of aluminosilicate $[25,30]$, leading to a decrease in strength.

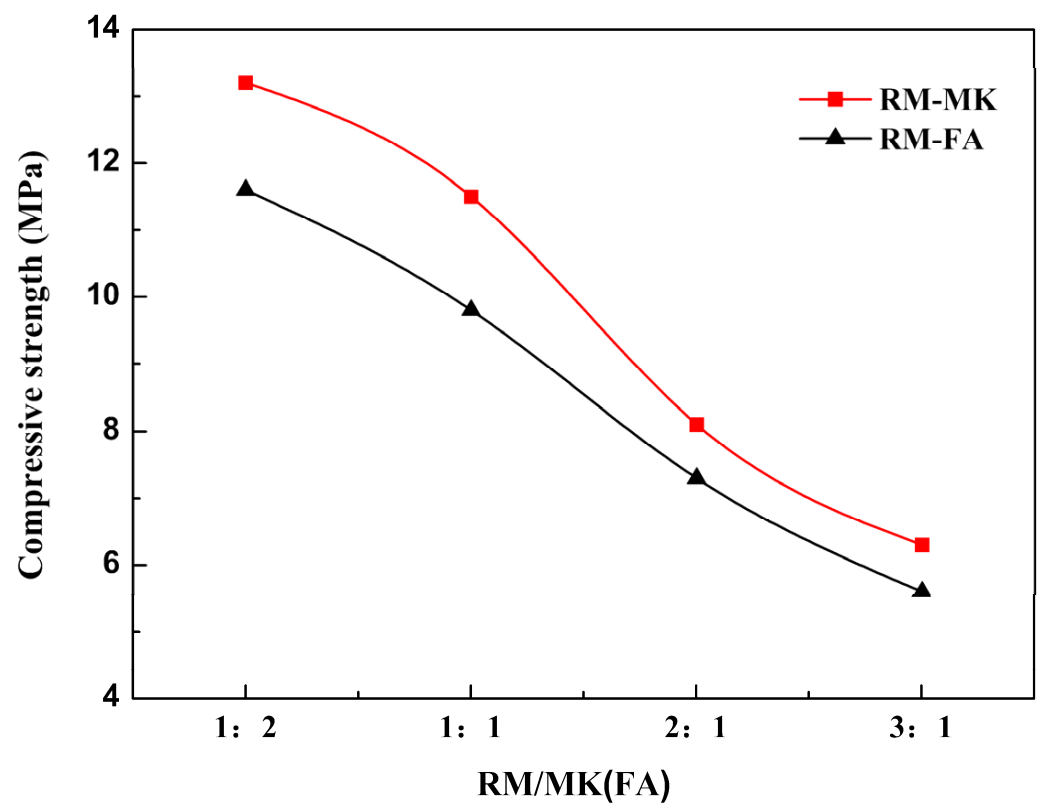

(a) Curing at room temperature

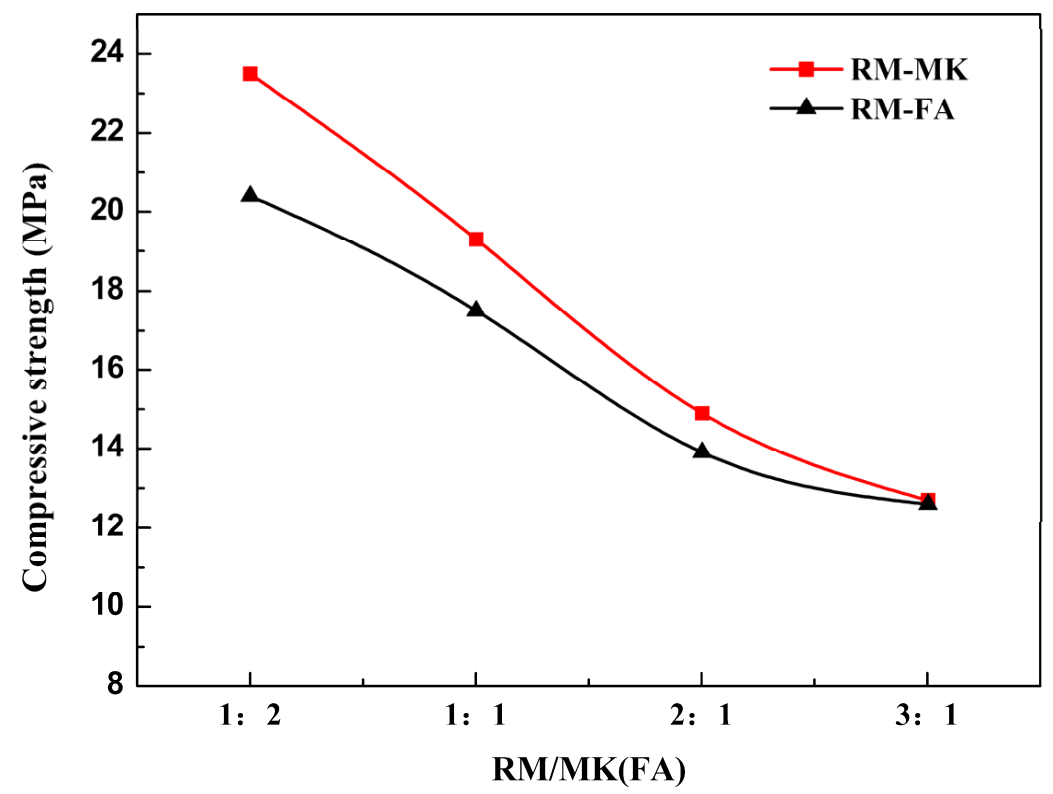

(b) Curing at $80^{\circ} \mathrm{C}$

Figure 3. Cont. 


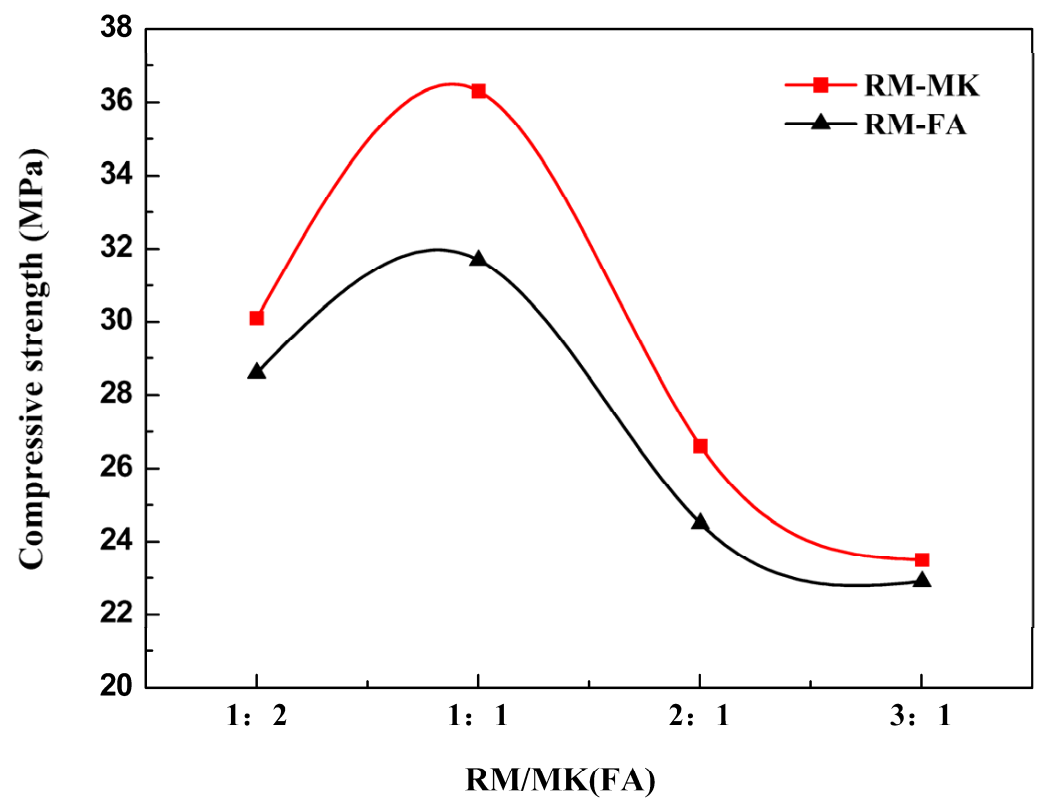

(c) Curing in the autoclave

Figure 3. Variation in geopolymer compressive strength with red mud content.

Amazingly, curing in the autoclave, the compressive strength increases first and then decreases with an increase in the red mud proportion. When the red mud content is $50 \%$, the strength of the geopolymer reaches its maximum value, for the RM-KM geopolymer this being $36.3 \mathrm{MPa}$ and for the RM-FA geopolymer 31.7 MPa. This is different from the results obtained under the previous two curing methods. It has been stated that the $\mathrm{SiO}_{2}$ in the red mud began to dissolve and participated in polymerization under a high-pressure condition in previous work. The $\mathrm{Si}-\mathrm{O}$ bond broke and then recombined, and stronger $\mathrm{Si}-\mathrm{O}-\mathrm{Si}$ bonds and $\mathrm{Si}-\mathrm{O}-\mathrm{Al}$ bonds were formed. Thus, a stable three-dimensional network polymer structure was framed. In addition, the residual alkali in the red mud accelerates the dissolution of the raw materials and promotes the synthesis of the geopolymer [40]. However, the dissolution rate of the raw material and the subsequent polymerization reaction rate are limited as the red mud content increases. As a result, the intensity goes down. From the above results, the first step of geological polymerization (the dissolution of silicoaluminate raw material in alkaline solution) plays a very critical role in the whole polymerization process. When the synthesis condition was changed, the role of the $\mathrm{SiO}_{2}$ in the red mud changed from an inactive filler to active substance. Therefore, a highstrength geopolymer with $50 \%$ red mud content can be obtained when curing under high temperature and high pressure in an autoclave. High red mud usage, given the excellent mechanical properties of its products, provides a possibility for its extensive application in the field of building materials.

In previous studies, the strength of the geopolymer decreased with an increase in red mud content. Generally, the best dosage of red mud was $20-40 \%[32,40]$. In this study, the effect of curing methods on the compressive strength of the red mud geopolymers was studied, and the microstructure of the geopolymers was characterized. Compared with previous studies, the preparation of a geopolymer with red mud in the autoclave not only can obtain a high-strength geopolymer but also ensures the best use of red mud, up to $50 \%$, which is something we did not find before. 


\subsection{X-ray Diffraction (XRD) Analysis}

Figure 4 shows the XRD patterns of the geopolymers with a $50 \%$ red mud content solidified under different conditions. The XRD patterns of the red mud-metakaolin geopolymer and red mud-fly ash geopolymer have similar changes in phase structure.

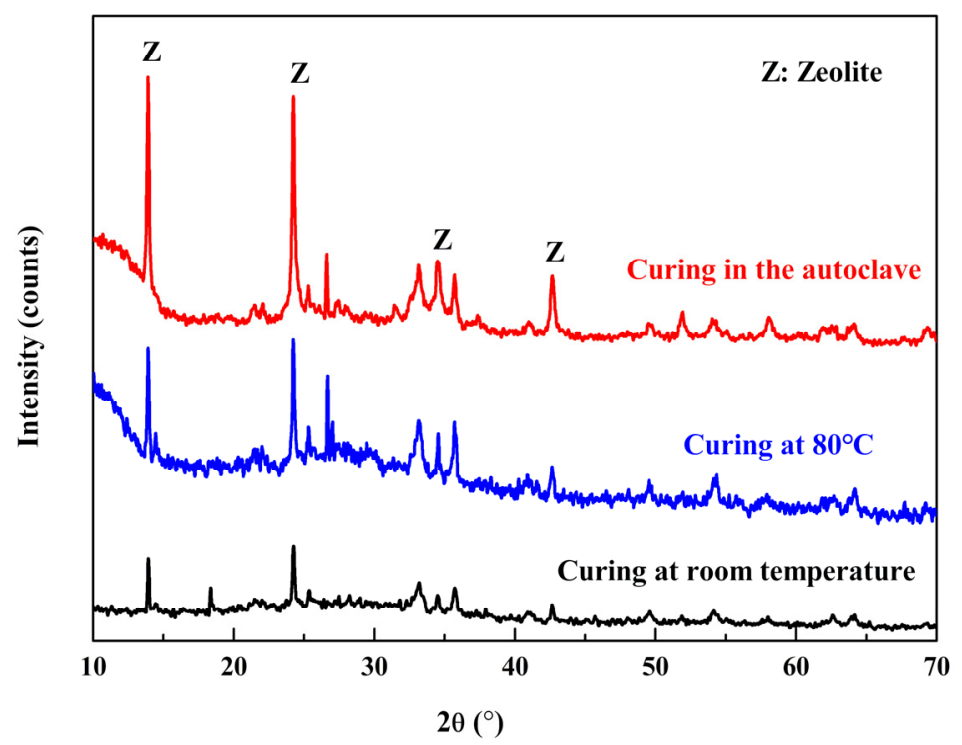

(a) RM-MK geopolymers

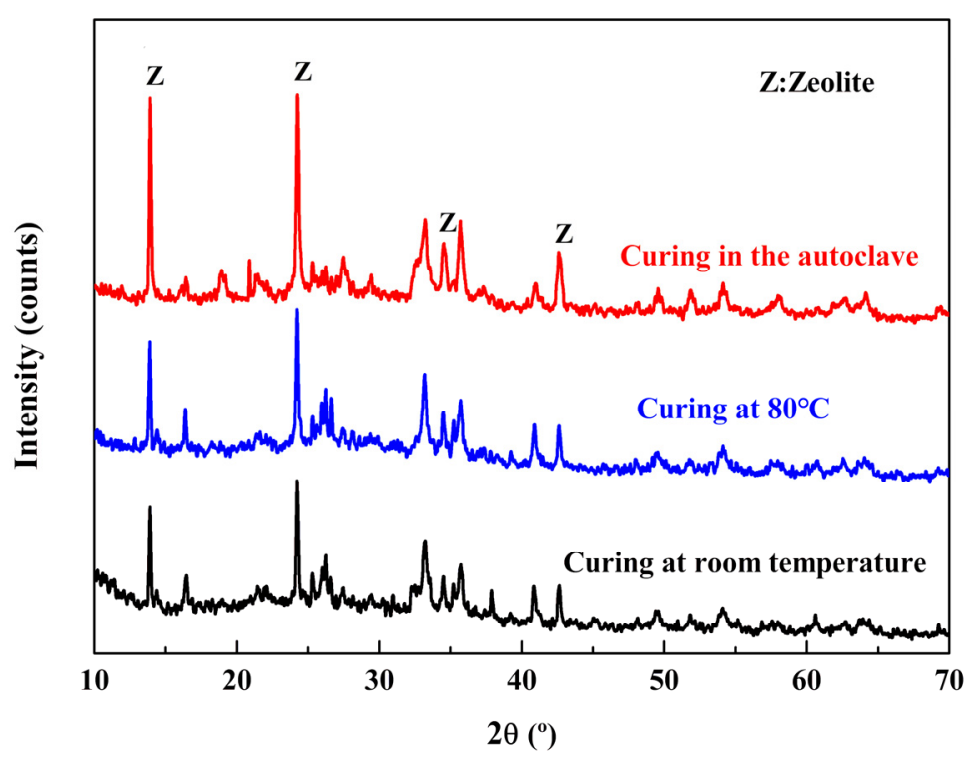

(b) RM-FA geopolymers

Figure 4. XRD pattern of the geopolymers with a 50\% red mud content.

In the XRD pattern, the zeolite phases can be clearly observed. The diffraction peak intensity of the zeolite phases increases gradually with an increase in curing temperature and pressure. A large number of zeolite minerals in the geopolymer cured in the autoclave indicate that the degree of polymerization of the $\left[\mathrm{SiO}_{4}\right]$ and $\left[\mathrm{AlO}_{4}\right]$ monomers is maximized [41].

\subsection{Scanning Electron Microscopy (SEM) Analysis}

Figure 5 shows the microstructure of the geopolymers with a red mud content of $50 \%$ cured under different systems. The SEM of the RM-MK geopolymer is shown in 
Figure 5. Curing at room temperature (Figure 5a), the geopolymer is made up of porous, loose gel particles. As the curing temperature increases (curing at $80^{\circ} \mathrm{C}$ ) (Figure 5b), the porosity between the cementing products decreases and the density improves. Curing in the autoclave (Figure $5 \mathrm{c}$ ), the geopolymer shows continuous and denser gels, indicating that the degree of polymerization of the geopolymer is further improved. A small part of the unreacted raw materials and the zeolite crystal structure is embedded in the geopolymer gel phase to form a uniform and dense structure, bringing about a high strength and stiffness of the geopolymer. The same conclusion can be obtained in the microstructure of the RM-FA geopolymer in Figure 6.

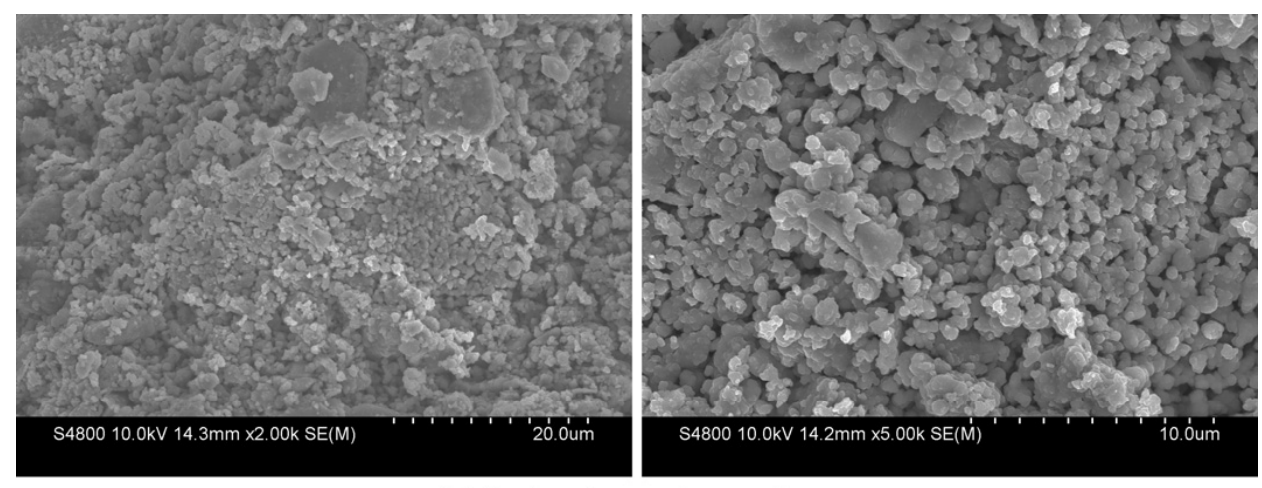

(a) Curing at room temperature

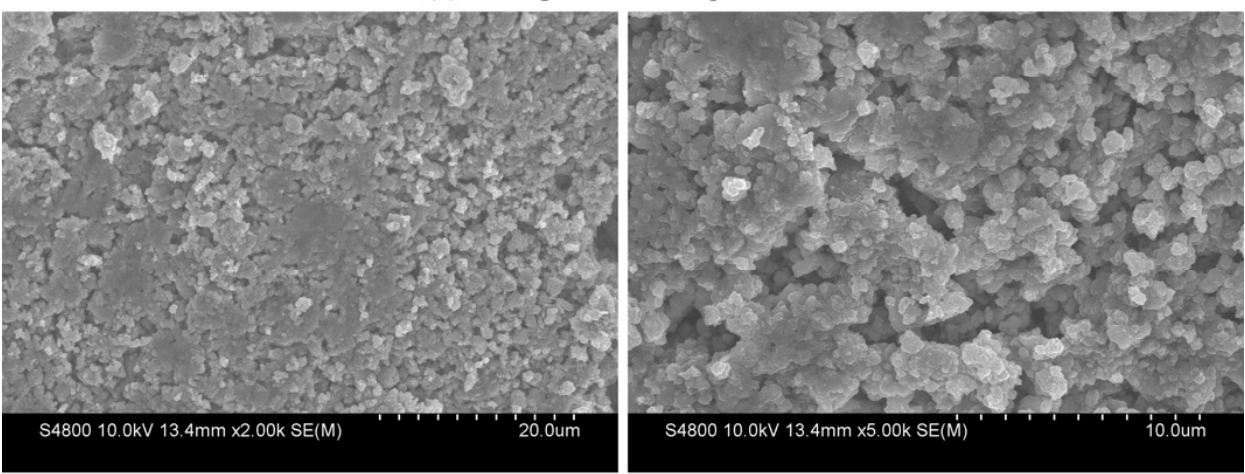

(b) Curing at $80^{\circ} \mathrm{C}$
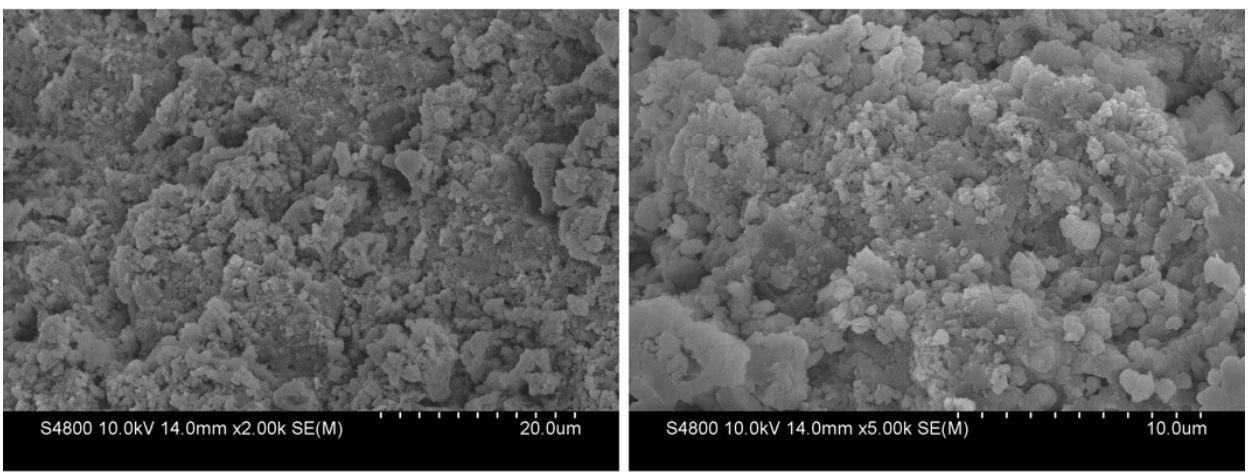

(c) Curing in autoclave

Figure 5. SEM micrographs of the RM-MK geopolymers with a 50\% red mud content. 

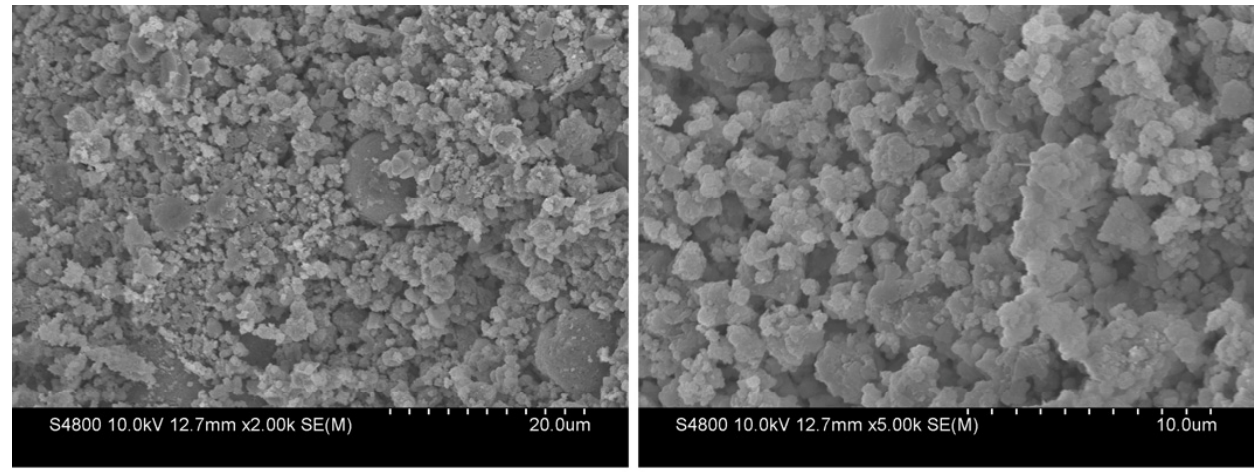

(a) Curing at room temperature
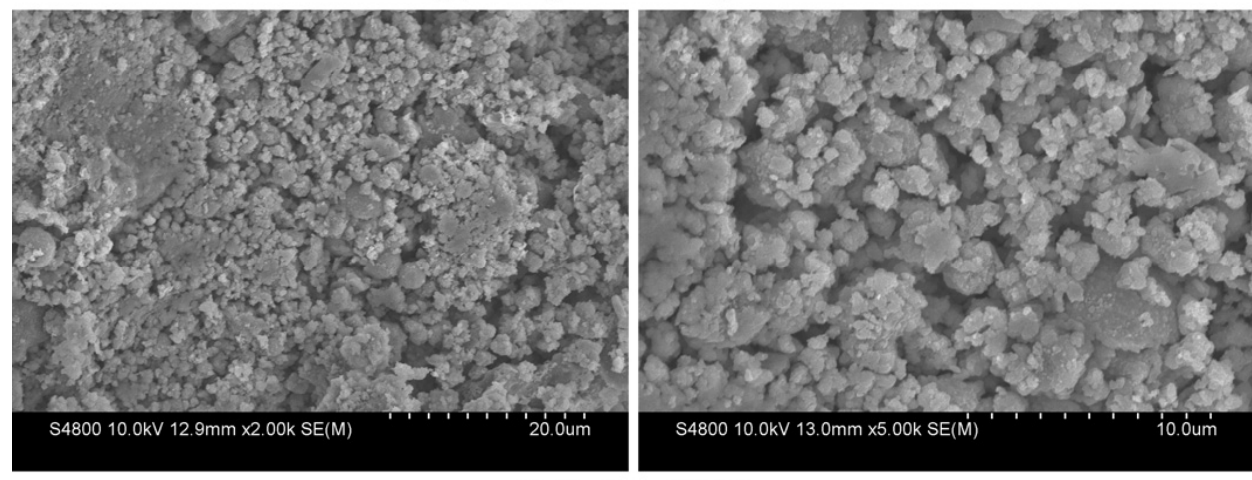

(b) Curing at $80^{\circ} \mathrm{C}$

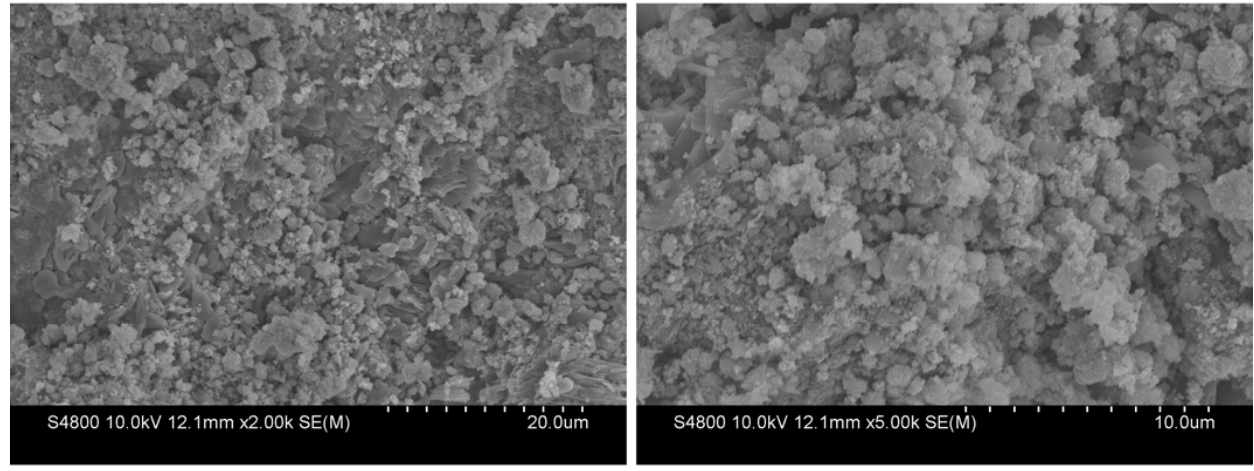

(c) Curing in autoclave

Figure 6. SEM photography of the RM-FA geopolymers with a 50\% red mud content.

\section{Conclusions}

In this paper, three curing methods were studied, namely, room temperature, $80{ }^{\circ} \mathrm{C}$, and high pressure in an autoclave. The mechanical properties and microstructure of the geopolymers were examined by changing the proportion of red mud. The crucial conclusions obtained from the experimental results are as follows:

1. The curing system affects the synthesis and mechanical properties of the geopolymers tremendously. Curing at room temperature and $80^{\circ} \mathrm{C}$, the higher the proportion of red mud, the lower the strength of the geopolymer. Yet, curing at high pressure, the higher red mud content improves the strength. A 50\% red mud content is the optimal value at which the geopolymers have their highest compressive strength.

2. The curing method affects the first step of the polymerization of the red mud-based polymer: dissolution of aluminosilicate in an alkali solution. Compared with curing under atmospheric pressure, autoclave solidification can make it possible for the silica in the red mud to dissolve in an alkaline solution, and a more silica-rich gel phase is produced. Furthermore, the alkali in the red mud accelerates the dissolution of the aluminosilicate under high pressure. 
3. The results of the XRD and SEM analyses show that more amorphous silicate gel products and zeolite structures are generated at a high pressure. This result illustrates that the geopolymer reaction is more sufficient. With the decrease in porosity and the densification of the structure, the geopolymers show good mechanical properties.

\begin{abstract}
Author Contributions: Conceptualization, T.A.; methodology, D.Z.; validation, Y.Z. and X.Y.; formal analysis, T.A.; investigation, J.Z.; resources, T.A.; data curation, D.Z.; writing-original draft preparation, D.Z.; writing-review and editing, T.A. and D.Z.; supervision, T.A.; project administration, Y.N.; funding acquisition, Y.N. All authors have read and agreed to the published version of the manuscript.

Funding: This research was funded by the Special Fund for Basic Scientific Research of Central Colleges, Chang'an University (No. 300102310301), the Fundamental Research Funds for the Central Universities, CHD (No.300102311404), and the National Undergraduate Innovation and Entrepreneurship Training Program(S202010710204).
\end{abstract}

Conflicts of Interest: The authors declare no conflict of interest.

\title{
References
}

1. Zeng, H.; Lyu, F.; Sun, W.; Zhang, H.; Wang, L.; Wang, Y. Progress on the Industrial Applications of Red Mud with a Focus on China. Minerals 2020, 10, 773. [CrossRef]

2. Li, Z.; Zhang, J.; Li, S.; Lin, C.; Gao, Y.; Liu, C. Feasibility of preparing red mud-based cementitious materials: Synergistic utilization of industrial solid waste, waste heat, and tail gas. J. Clean. Prod. 2020, 285, 124896. [CrossRef]

3. Wang, P.; Liu, D.-Y. Physical and Chemical Properties of Sintering Red Mud and Bayer Red Mud and the Implications for Beneficial Utilization. Materials 2012, 5, 1800-1810. [CrossRef]

4. Jiang, X.; Xiao, R.; Zhang, M.; Hu, W.; Bai, Y.; Huang, B. A laboratory investigation of steel to fly ash-based geopolymer paste bonding behavior after exposure to elevated temperatures. Constr. Build. Mater. 2020, 254, 119267. [CrossRef]

5. Joseph, C.G.; Taufiq-Yap, Y.H.; Krishnan, V.; Puma, G.L. Application of modified red mud in environmentally-benign applications: A review paper. Environ. Eng. Res. 2019, 25, 795-806. [CrossRef]

6. Sutar, H.; Mishra, S.C. Progress of Red Mud Utilization: An Overview. Am. Chem. Sci. J. 2014, 4, 255-279. [CrossRef]

7. Wang, S.; Jin, H.; Deng, Y.; Xiao, Y. Comprehensive utilization status of red mud in China: A critical review. J. Clean. Prod. 2020, 289, 125136. [CrossRef]

8. Xu, X.; Song, J.; Li, Y.; Wu, J.; Liu, X.; Zhang, C. The microstructure and properties of ceramic tiles from solid wastes of Bayer red muds. Constr. Build. Mater. 2019, 212, 266-274. [CrossRef]

9. Zhao, Y.R.; Chen, P.; Wei, H.J.; Zhang, J.F.; Liu, R.J. Preparation of Belite sulphate aluminum cement with fly ash and Bayer process red mud. J. Guilin Univ. Technol. 2015, 35, 581-584.

10. Qi, J.Z.; Yang, J.K.; Wang, M.; Xiao, B.; Hou, J. Experimental research on red mud as road base material. J. Highw. Transp. Res. Dev. 2005, 06, 30-33.

11. Yang, J.; Zhang, D.; Hou, J.; He, B.; Xiao, B. Preparation of glass-ceramics from red mud in the aluminium industries. Ceram. Int. 2008, 34, 125-130. [CrossRef]

12. Sudhir, M.R.; Beulah, M.; Sasha Rai, P.; Gayathri, G. A microstructure exploration and compressive strength determination of red mud bricks prepared using industrial wastes. Mater. Today Proc. 2020, 46, 163-169. [CrossRef]

13. Zhao, Y.; Liang, N.; Chen, H.; Yuan, L.I. Preparation and properties of sintering red mud unburned road brick using orthogonal experiments. Constr. Build. Mater. 2020, 238, 117739. [CrossRef]

14. Arroyo, F.; Luna-Galiano, Y.; Leiva, C.; Vilches, L.F.; Fernández-Pereira, C. Environmental risks and mechanical evaluation of recycling red mud in bricks. Environ. Res. 2020, 186, 109537. [CrossRef]

15. Liu, W.C.; Yan, K.; He, X.Z.; Zhang, C.P.; Wu, G.L. Research progress on the preparation of geopolymer inorganic polymer materials from Bayer process red mud. Bull. Chin. Ceram. Soc. 2016, 35, 453-457.

16. Khairul, M.A.; Zanganeh, J.; Moghtaderi, B. The composition, recycling and utilisation of Bayer red mud. Resour. Conserv. Recycl. 2019, 141, 483-498. [CrossRef]

17. He, J.; Jie, Y.; Zhang, J.; Yu, Y.; Zhang, G. Synthesis and characterization of red mud and rice husk ash-based geopolymer composites. Cem. Concr. Compos. 2013, 37, 108-118. [CrossRef]

18. Davidovits, J. Geopolymers: Ceramic-Like Inorganic Polymers. J. Ceram. Sci. 2017, 8, 335-350.

19. Wan, Q.; Rao, F.; Song, S.; García, R.E.; Estrella, R.M.; Patino, C.L.; Zhang, Y. Geopolymerization reaction, microstructure and simulation of metakaolin-based geopolymers at extended Si/Al ratios. Cem. Concr. Compos. 2017, 79, 45-52. [CrossRef]

20. Davidovits, J. GEOPOLYMERS Inorganic polymerie new materials. J. Ofthamal Anal. 1991, 37, 1633-1656.

21. Duxson, P.; Fernández-Jiménez, A.; Provis, J.L.; Lukey, G.C.; Palomo, A.; van Deventer, J.S. Geopolymer technology: The current state of the art. J. Mater. Sci. 2006, 42, 2917-2933. [CrossRef]

22. Zhang, S.Z.; Gong, K.C. Geopolymer. J. Mater. Sci. Eng. 2003, 03, 430-436. 
23. Provis, J.L.; Bernal, S.A. Geopolymers and Related Alkali-Activated Materials. Annu. Rev. Mater. Res. 2014, 44, 299-327. [CrossRef]

24. Van Deventer, J.S.J.; Provis, J.L.; Duxson, P. Technical and commercial progress in the adoption of geopolymer cement. Miner. Eng. 2012, 29, 89-104. [CrossRef]

25. Liang, X.; Ji, Y. Preparation sequences and pretreatment optimization of alkali-activated red mud and blast furnace slag-based materials. J. Mater. Cycles Waste Manag. 2020, 23, 259-271. [CrossRef]

26. Wang, H.; Li, H.; Yan, F. Synthesis and mechanical properties of metakaolinite-based geopolymer. Colloids Surf. A Physicochem. Eng. Asp. 2005, 268, 1-6. [CrossRef]

27. Nie, Q.; Hu, W.; Ai, T.; Huang, B.; Shu, X.; He, Q. Strength properties of geopolymers derived from original and desulfurized red mud cured at ambient temperature. Constr. Build. Mater. 2016, 125, 905-911.

28. Hanayneh, B. Influence of Curing Conditions on the Properties of Geopolymers from Untreated Kaolinite. J. Am. Sci. 2014, 10, $42-49$.

29. Zheng, L.; Wang, W.; Shi, Y. The effects of alkaline dosage and Si / Al ratio on the immobilization of heavy metals in municipal solid waste incineration fly ash-based geopolymer. Chemosphere 2010, 79, 665-671. [CrossRef] [PubMed]

30. Hajimohammadi, A.; Provis, J.L.; van Deventer, J.S.J. Effect of Alumina Release Rate on the Mechanism of Geopolymer Gel Formation. Chem. Mater. 2010, 22, 5199-5208. [CrossRef]

31. Perera, D.S.; Uchida, O.; Vance, E.R.; Finnie, K.S. Influence of curing schedule on the integrity of geopolymers. J. Mater. Sci. 2006, 42, 3099-3106. [CrossRef]

32. Kumar, A.; Kumar, S. Development of paving blocks from synergistic use of red mud and fly ash using geopolymerization. Constr. Build. Mater. 2013, 38, 865-871. [CrossRef]

33. Kani, E.N.; Allahverdi, A. Effects of curing time and temperature on strength development of inorganic polymeric binder based on natural pozzolan. J Mater Sci. 2009, 44, 3088-3097. [CrossRef]

34. Zhang, M.; Zhao, M.; Zhang, G.; Sietins, J.M.; Granados-Focil, S.; Pepi, M.S.; Xu, Y.; Tao, M. Reaction kinetics of red mud-fly ash based geopolymers: Effects of curing temperature on chemical bonding, porosity, and mechanical strength. Cem. Concr. Compos. 2018, 93, 175-185. [CrossRef]

35. Kaya, K.; Soyer-Uzun, S. Evolution of structural characteristics and compressive strength in red mud-metakaolin based geopolymer systems. Ceram. Int. 2016, 42, 7406-7413. [CrossRef]

36. Hoang, M.D.; Do, Q.M.; Le, V.Q. Effect of curing regime on properties of red mud based alkali activated materials. Constr. Build. Mater. 2020, 259, 119779. [CrossRef]

37. Liu, J.; Li, X.; Lu, Y.; Bai, X. Effects of $\mathrm{Na} / \mathrm{Al}$ ratio on mechanical properties and microstructure of red mud-coal metakaolin geopolymer. Constr. Build. Mater. 2020, 263, 120653. [CrossRef]

38. Dimas, D.D.; Giannopoulou, I.P.; Panias, D. Utilization of Alumina Red Mud for Synthesis of Inorganic Polymeric Materials. Miner. Process. Extr. Metall. Rev. 2009, 30, 211-239. [CrossRef]

39. Criado, M.; Fernández-Jiménez, A.; Palomo, A. Alkali activation of fly ash. Part III: Effect of curing conditions on reaction and its graphical description. Fuel 2010, 89, 3185-3192. [CrossRef]

40. Hu, W.; Nie, Q.; Huang, B.; Shu, X.; He, Q. Mechanical and microstructural characterization of geopolymers derived from red mud and fly ashes. J. Clean. Prod. 2018, 186, 799-806. [CrossRef]

41. Khale, D.; Chaudhary, R. Mechanism of geopolymerization and factors influencing its development: A review. J. Mater. Sci. 2007, 42, 729-746. [CrossRef] 